\title{
Vitamin D Status and Its Association with Multiple Intelligence among Arab Adolescents
}

\author{
Ahmed S. Mohammed Metwally ${ }^{1}\left(\mathbb{D}\right.$, Sobhy M. Yakout ${ }^{2}$, Malak N. K. Khattak ${ }^{2} \mathbb{D}$, Ghadah Alkhaldi $^{3} \mathbb{D}$ \\ and Nasser M. Al-Daghri ${ }^{2, *(D)}$ \\ 1 Department of Mathematics, College of Science, King Saud University, Riyadh 11451, Saudi Arabia; \\ dalsayed@ksu.edu.sa \\ 2 Biochemistry Department, King Saud University, Riyadh 11451, Saudi Arabia; \\ sobhy.yakout@gmail.com (S.M.Y.); malaknawaz@yahoo.com (M.N.K.K.) \\ 3 Department of Community Health Sciences, College of Applied Medical Sciences, King Saud University, \\ Riyadh 11451, Saudi Arabia; ghalkhaldi@ksu.edu.sa \\ * Correspondence: aldaghri2011@gmail.com; Tel.: +966-114675939
}

check for updates

Citation: Metwally, A.S.M.; Yakout, S.M.; Khattak, M.N.K.; Alkhaldi, G.; Al-Daghri, N.M. Vitamin D Status and Its Association with Multiple Intelligence among Arab Adolescents. Int. J. Environ. Res. Public Health 2021, 18, 13036. https://doi.org/10.3390/ ijerph182413036

Academic Editors: Ryan D. Burns and Wonwoo Byun

Received: 2 November 2021

Accepted: 9 December 2021

Published: 10 December 2021

Publisher's Note: MDPI stays neutral with regard to jurisdictional claims in published maps and institutional affiliations.

Copyright: (c) 2021 by the authors. Licensee MDPI, Basel, Switzerland. This article is an open access article distributed under the terms and conditions of the Creative Commons Attribution (CC BY) license (https:/ / creativecommons.org/licenses/by/ $4.0 /$ )

\begin{abstract}
Studies investigating the association of vitamin D on intelligence is limited. The present study therefore aims to determine the association of vitamin D status with the different domains of intelligence among Saudi Arabian adolescents. This study used relational survey method among 1864 Saudi adolescent, including 549 boys and 1315 girls (mean age $14.7 \pm 1.7$ years) recruited using a multistage, stratified cluster randomization of 47 public and private schools in Riyadh in Saudi Arabia. A general questionnaire was used to collect demographic information. Intelligence was assessed using multiple intelligence inventory. Anthropometrics were measured and fasting blood samples collected for assessment of glucose and lipid profile. Vitamin D deficiency $(25(\mathrm{OH}) \mathrm{D}<50 \mathrm{nmol} / \mathrm{L})$ was observed in $84.2 \%$ of boys and $93.5 \%$ of girls. Girls had higher levels of verbal, kinesthetic, musical, naturalist and existential intelligence than boys, while boys have higher logical intelligence than girls ( $p$-values $<0.05$ ). Mixed regression analysis controlled for age, BMI and sex revealed that kinesthetic intelligence was significantly associated with $25(\mathrm{OH}) \mathrm{D}$ in boys $(\beta 5.6(2.8-8.5 ; p<0.001))$ and inversely associated with musical intelligence $(\beta-1.2(-2.3-0.1 ; p=0.03))$ and positively with naturalist $(\beta 2.3(0.5-4.2 ; p=0.01))$ in girls. Vitamin D status is associated with several domains of intelligence in adolescents and is sex-specific. Development a specific domain of intelligence may indirectly affect vitamin D status among adolescents, but needs to be proven prospectively.
\end{abstract}

Keywords: secondary school; multiple intelligence; vitamin D

\section{Introduction}

Intelligence is the capacity to learn new knowledge and skills to solve problems. It reveals the ability to understand environments [1]. Most definitions of intelligence focus on academic success [1,2], but it is acknowledged that other components of intelligence such as problem-solving cannot be probed sufficiently in short-answer tests [3], hence the need for other assessment tools that go beyond conventional measures of acquired skills [3-5].

Based on psychometric as well as neuropsychological evidence, Gardner suggested that there are multiple intelligences or cognitive abilities in normal individuals as well as "special populations" such as prodigies, savants, autistic individuals and learningdisabled children (modern multiple intelligence theory) [6,7]. Gardner described nine types of intelligence: (i) linguistic, (ii) logical, (iii) spatial, (iv) interpersonal, (v) naturalistic, (vi) intrapersonal, (vii) kinesthetic, (viii) musical and (ix) existential, all of which interact and work together in complex ways [8]. These multiple intelligences when assessed correctly can aid instructors identify the students' maximum potential $[9,10]$.

The theory of multiple intelligence suggests that each person has varying capacity in all nine intelligences and everyone has the ability to develop all if given the suitable envi- 
ronment and conditions [10]. The application of this theory is crucial in maximizing human cognitive capability and efficiency [11]. Cultivating each type of intelligence in students elevates academic performance [12,13] and identifies the gifted individuals [14-16].

Vitamin D is an essential micronutrient important for calcium homeostasis and bone growth. The extra-skeletal effects of vitamin D has been of great interest in the recent years, with vitamin D status affecting almost every aspect of metabolism from fetal development until adulthood [17-19], including major outcomes to diseases and even epidemics [20-23]. Furthermore, vitamin D has several biological actions related to neurodevelopment and brain function [24]. A strong relationship between vitamin D deficiency, cognitive function and behavior have been documented in animal models and observational studies [25]. Vitamin D receptor (VDR) and enzymes necessary for vitamin D activation are found in the brain which can convert 25(OH)D into 1,25(OH)2D, the active metabolite [26]. This can influence several neurologic processes including cell differentiation, neurotransmitter synthesis, antioxidant effects, intracellular calcium homeostasis, neuronal development, metabolism and cognitive function [26]. Sunlight represents one of the main sources for vitamin D and is also found in some food sources [27]. On a global level, vitamin $\mathrm{D}$ deficiency is a major public health problem [28], including Saudi Arabia (SA) where despite abundant sunshine, there is still a high prevalence of vitamin D deficiency (SA) at 73.2\% [29]. The (Middle East and North Africa) MENA region on the other hand, has vitamin D deficiency prevalence ranging from $54 \%$ to $90 \%$ in adults [30].

Studies investigating the relationship between vitamin $\mathrm{D}$ status and cognitive function are mostly observational with mixed results from scant clinical trials [31]. Nevertheless, evidence from the last 16 years concerning people with learning disabilities were recently reviewed and found that vitamin $D$ deficiency prevalence in this population ranges from $49-77 \%$, considerably higher than the general population [32]. Another recent study observed that maternal vitamin D status is positively linked to intelligence quotient (IQ) in children aged 4-6 years [33]. These studies while suggestive, still needs to be taken into context, given the numerous factors that can affect cognition. Nevertheless, there is still a need to further identify the extent of vitamin D status' influence on brain health, including intelligence. To the best of our knowledge, the association of vitamin D status with the different domains of intelligence has never been investigated. Such studies may offer new insights as to which domains of intelligence can be influenced by micronutrient deficiencies such as vitamin D deficiency. To fill this gap, the purpose of the present study is to examine if there is an association between vitamin D status with the different types of intelligence among Arab adolescents.

\section{Materials and Methods}

\subsection{Participants}

A total of 1864 apparently healthy Saudi adolescent boys $(\mathrm{N}=549)$ and girls $(\mathrm{N}=1315)$ aged 13-17 (mean age 14.7 \pm 1.7 years) from different public, private schools within Riyadh, SA were invited to participate in this cross-sectional study from November 2019 until March 2020 before the national lockdown was imposed. The capital Riyadh, from where the sampling frame was taken, is divided into four regions (North, South, East and West). A multistage stratified cluster random technique was then used to recruit the participants wherein schools were chosen randomly in each region, and one class is randomly selected from each grade level, leaving the other classes, and all students from the selected class were encouraged to participate. Consent from parents and assent from students were obtained prior to inclusion.

Sample size calculation was done online (Raosoft.com) given 2\% margin of error at 95\% confidence interval and 10\% response distribution in Riyadh, the minimum recommended sample size should be $N=829$. Out of the 2650 students invited, 1864 consented to participate and provide fasting blood samples ( $70.3 \%$ response rate).

Ethical approval was obtained from the Ethics Committee of the College of Science Research Center, King Saud University, Riyadh, SA (No. E-19-239 on 29 October 2019). 
Two questionnaires were administered to all students: the demographic questionnaire and the McKinsey Multiple Intelligence (MI) Inventory [34,35], to identify the typology of intelligence. The introspective domain consists of existential, intrapersonal and visual intelligences (Figure 1). The second part had 90 questions in Likert scale format (1-2-3-4-5) to assess the nine intelligences proposed by Gardner [6]: verbal (Linguistic), logical, visual, kinesthetic, musical (rhythmic), intrapersonal, interpersonal and naturalist existential. MI can be divided to three domains: the analytical, introspective and interactive domains. These domains help in understanding the fluid relationship of the intelligences and how they work with one another. Figure 1 presents each domain and its sub-branches in details.

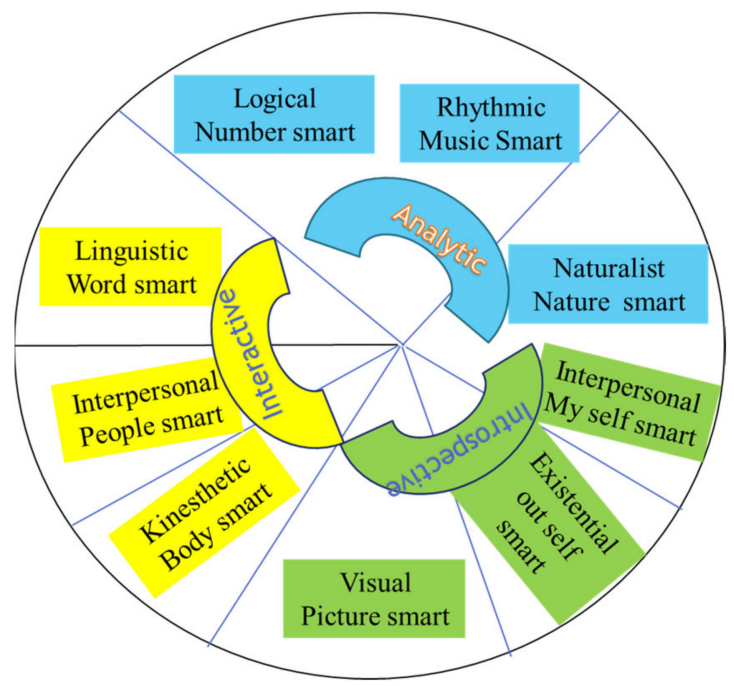

Figure 1. Multiple Intelligence Domains.

\subsection{Anthropometric and Biochemical Parameters}

Anthropometric data and fasting blood extraction were performed in schools at a designated date and facilitated by the school physician (if available) or well-trained research nurses working in collaboration with the Chair for Biomarkers of Chronic Diseases (CBCD) in King Saud University (KSU), Riyadh, SA. Anthropometrics included weight $(\mathrm{kg})$, height $(\mathrm{cm})$, waist $(\mathrm{cm})$, hips $(\mathrm{cm})$ and blood pressure $(\mathrm{mmHg})$. Fasting blood samples $(5 \mathrm{cc}$ ) was collected and stored using non-heparinized tubes and transported immediately to $\mathrm{CBCD}$ in KSU, Riyadh, KSA for storage at $-20^{\circ} \mathrm{C}$. Fasting blood glucose and lipid profile (triglycerides, total and HDL-cholesterol) were assessed using Konelab (Vintaa, Finland). LDL-cholesterol was calculated using the Friedewald formula. Serum 25-Hydroxyvitamin $(\mathrm{OH}) \mathrm{D}$ was measured using COBAS e-411 automated analyzer (Roche Diagnostics, Indianapolis, IN, USA) in a DEQAS-certified laboratory (CBCD) [29]. For serum 25-hydroxyvitamin D assay, the inter- and intra-assay coefficients of variation (CV) were $8.0 \%$ and $5.6 \%$, respectively, with a lower detection limit (LOD) of $<4 \mathrm{ng} / \mathrm{mL}$ ) [29]. Vitamin D deficiency was defined as $25(\mathrm{OH}) \mathrm{D}<50 \mathrm{nmol} / \mathrm{L}[19,20]$.

\subsection{Data Analysis}

Data were analyzed using SPSS (version 24 Chicago, IL, USA). Continuous data were presented as mean \pm standard deviation (SD) for normal variables and non-normal variables were presented in median (1st and 3rd) percentiles. Categorical data were presented as frequencies. All continuous variables were checked for normality using Kolmogorov-Smirnov test. Independent T-test was used to compare mean differences. Correlations between variables were done using Pearson's correlation analysis. MixedEffect regression analysis was performed using $25(\mathrm{OH}) \mathrm{D}$ as dependent variable and MI as independent variables, controlled for age and BMI and stratified according to sex. A $p$-value $<0.05$ was considered statistically significant. 


\section{Results}

The demographic and clinical characteristics as well as MI scores of boys and girls are shown in Table 1. Vitamin D deficiency was noted in $84.2 \%$ of the boys and $93.5 \%$ of the girls (not shown in table). Boys were significantly older, had higher BMI, WHR, glucose, HDL, triglycerides and 25(OH)D than girls ( $p$-values $<0.05)$ while girls had higher total cholesterol than boys $(p=0.04)$. In terms of MI, girls have significantly higher verbal $(p=0.02)$, kinesthetic $(p=0.047)$, musical $(p<0.001)$ naturalist $(p=0.019)$ and existential intelligences $(p=0.004)$ than boys. However, boys have only significantly higher logical intelligences $(p=0.03)$. No further significant differences were found.

Table 1. Differences in Clinical Characteristics and MI Scores of Boys and Girls.

\begin{tabular}{|c|c|c|c|c|}
\hline Parameters & All & Boys & Girls & $p$-Value \\
\hline $\mathrm{N}$ & 1864 & 549 & 1315 & \\
\hline Age (years) & $14.7 \pm 1.7$ & $15.1 \pm 1.6$ & $14.6 \pm 1.7$ & $<0.001$ \\
\hline BMI $\left(\mathrm{kg} / \mathrm{m}^{2}\right)$ & $23.1 \pm 6.7$ & $23.9 \pm 6.7$ & $22.8 \pm 6.7$ & 0.003 \\
\hline WHR & $0.81 \pm 0.1$ & $0.88 \pm 0.1$ & $0.79 \pm 0.1$ & $<0.001$ \\
\hline Systolic BP (mmHg) & $118.5 \pm 16.2$ & $119.6 \pm 14.6$ & $118.1 \pm 16.8$ & 0.08 \\
\hline Diastolic BP (mmHg) & $72.4 \pm 12.0$ & $67.3 \pm 10.5$ & $74.6 \pm 11.9$ & $<0.001$ \\
\hline Glucose (mmol/L) & $5.2 \pm 0.6$ & $5.3 \pm 0.6$ & $5.1 \pm 0.5$ & $<0.001$ \\
\hline T-Cholesterol (mmol/L) & $4.4 \pm 0.7$ & $4.3 \pm 0.8$ & $4.4 \pm 0.7$ & 0.04 \\
\hline HDL-Cholesterol (mmol/L) & $0.98 \pm 0.2$ & $0.99 \pm 0.2$ & $0.97 \pm 0.2$ & 0.03 \\
\hline Triglycerides (mmol/L) & $1.1 \pm 0.5$ & $1.2 \pm 0.6$ & $1.1 \pm 0.4$ & $<0.001$ \\
\hline $25(\mathrm{OH}) \mathrm{D}(\mathrm{nmol} / \mathrm{L})$ & $31.8 \pm 14.4$ & $38.7 \pm 13.5$ & $28.9 \pm 13.8$ & $<0.001$ \\
\hline Verbal (Linguistic) & $3.4 \pm 0.6$ & $3.3 \pm 0.6$ & $3.4 \pm 0.7$ & 0.02 \\
\hline Logical & $3.4 \pm 0.7$ & $3.5 \pm 0.7$ & $3.4 \pm 0.7$ & 0.03 \\
\hline Visual & $3.4 \pm 0.7$ & $3.4 \pm 0.6$ & $3.5 \pm 0.7$ & 0.08 \\
\hline Kinesthetic & $3.5 \pm 0.7$ & $3.5 \pm 0.6$ & $3.6 \pm 0.7$ & 0.047 \\
\hline Musical (Rhythmic) & $3.2 \pm 0.8$ & $3.0 \pm 0.8$ & $3.3 \pm 0.8$ & $<0.001$ \\
\hline Intrapersonal & $3.7 \pm 0.6$ & $3.7 \pm 0.6$ & $3.7 \pm 0.6$ & 0.87 \\
\hline Interpersonal & $3.5 \pm 0.6$ & $3.5 \pm 0.6$ & $3.5 \pm 0.6$ & 0.12 \\
\hline Naturalist & $3.4 \pm 0.6$ & $3.3 \pm 0.6$ & $3.4 \pm 0.6$ & 0.02 \\
\hline Existential & $3.5 \pm 0.7$ & $3.5 \pm 0.7$ & $3.6 \pm 0.7$ & 0.004 \\
\hline Analytic & $3.3 \pm 0.6$ & $3.3 \pm 0.5$ & $3.4 \pm 0.6$ & 0.002 \\
\hline Interactive & $3.5 \pm 0.6$ & $3.4 \pm 0.6$ & $3.5 \pm 0.6$ & 0.26 \\
\hline Introspective & $3.6 \pm 0.6$ & $3.5 \pm 0.6$ & $3.6 \pm 0.5$ & 0.07 \\
\hline
\end{tabular}

Note: Data presented as coefficient (R), significant at $p<0.05$.

Table 2 shows the bivariate associations of $25(\mathrm{OH}) \mathrm{D}$ with MI in boys and girls. In all subjects, $25(\mathrm{OH}) \mathrm{D}$ showed a significant positive correlation with logical $(p<0.01)$, kinesthetic and intrapersonal intelligences as well as a significant inverse correlation with musical intelligences ( $p$-values $<0.05)$. Stratification according to sex revealed that in boys, $25(\mathrm{OH}) \mathrm{D}$ was positively associated with logical $(p<0.05)$ and kinesthetic $(p<0.01)$ intelligences while in girls, 25(OH)D was significantly associated with verbal, logical, visual, kinesthetic, naturalist and introspective ( $p$-values $<0.05)$. In terms of domain, girls have significantly higher $(p<0.05)$ introspective domain than boys (Table 2). Figure 2 shows the bivariate association between $\mathrm{MI}$ and $25(\mathrm{OH}) \mathrm{D}$ which showed the most significant correlation in boys (2A) and girls (2B). 
Table 2. Bivariate Associations of 25(OH)D with $\mathrm{MI}$ in Boys and Girls.

\begin{tabular}{cccc}
\hline Parameters & All & Boys & Girls \\
\hline $\mathrm{N}$ & $1864(549 / 1315)$ & 549 & 1315 \\
\hline Verbal & 0.00 & 0.05 & $0.02^{*}$ \\
\hline Logical & $0.06^{* *}$ & $0.09^{*}$ & $0.06^{*}$ \\
\hline Visual & 0.04 & 0.04 & $0.10^{* *}$ \\
\hline Kinesthetic & $0.05^{*}$ & $0.14^{* *}$ & $0.07^{* *}$ \\
\hline Musical & $-0.05^{*}$ & 0.03 & -0.01 \\
\hline Intrapersonal & $0.05^{*}$ & 0.08 & 0.04 \\
\hline Interpersonal & 0.03 & 0.02 & 0.03 \\
\hline Naturalist & 0.04 & 0.01 & $0.08^{* *}$ \\
\hline Existential & 0.01 & 0.06 & 0.03 \\
\hline Analytic & 0.02 & 0.06 & 0.05 \\
\hline Interactive & 0.03 & 0.08 & 0.05 \\
\hline Introspective & 0.04 & 0.07 & $0.06^{*}$ \\
\hline
\end{tabular}

Note: Data presented as coefficient $(\mathrm{R}),{ }^{*}$ denotes significance at 0.05 level; ${ }^{* *}$ denotes significance at 0.01 level.
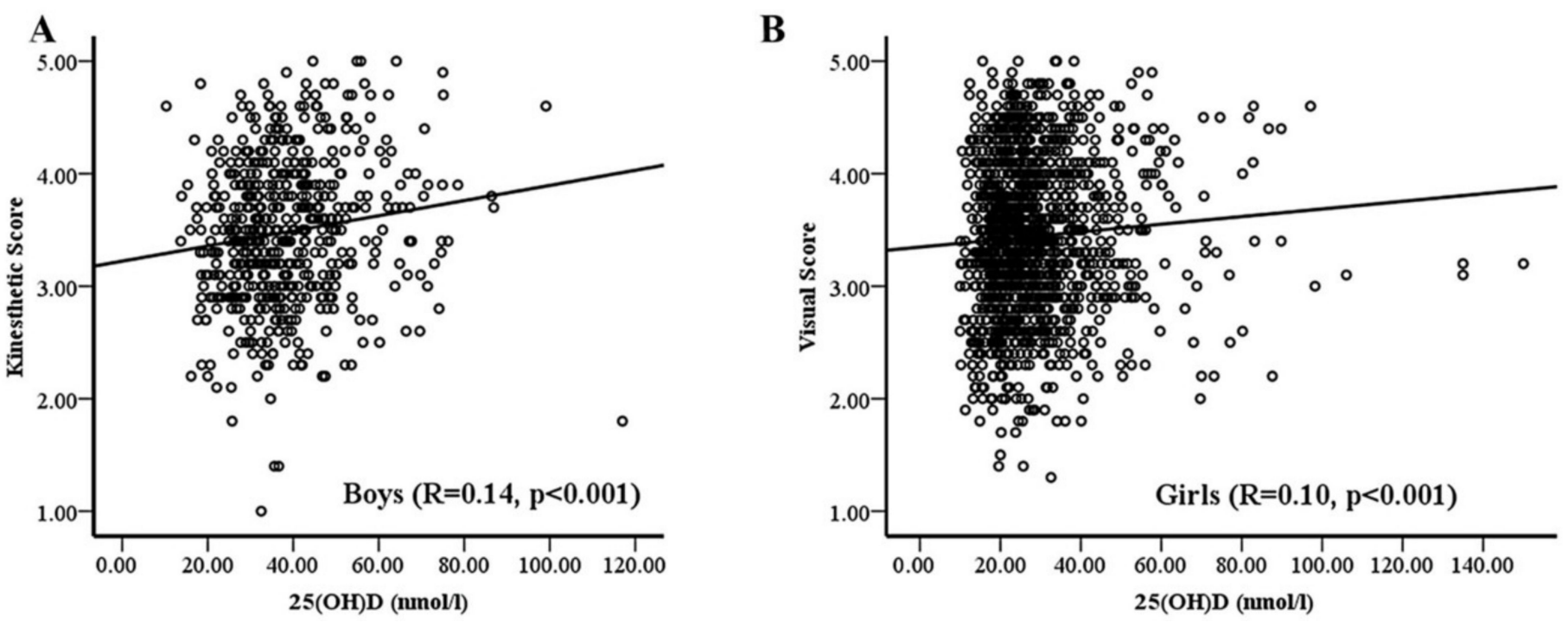

Figure 2. Unadjusted association of 25(OH)D with Kinesthetic Intelligence in Boys (A) and Visual Intelligence in Girls (B).

Mixed regression analysis using $25(\mathrm{OH}) \mathrm{D}$ as dependent variable with different $\mathrm{MI}$ as independent variables controlled for age and BMI, stratified for sex are shown in Table 3. Overall, verbal $(\beta-2.2(-3.9--0.5 ; p=0.01))$ and musical intelligences $(\beta-1.3(-2.2--0.4$; $p=0.004)$ ) showed a significant inverse association with $25(\mathrm{OH}) \mathrm{D}$. Stratified according to sex, only kinesthetic intelligence was significantly associated with $25(\mathrm{OH}) \mathrm{D}$ in boys $(\beta 5.6(2.8-8.5 ; p<0.001))$ while in girls, $25(\mathrm{OH}) \mathrm{D}$ was inversely associated with musical intelligence $(\beta-1.2(-2.3-0.1 ; p=0.03))$ and positively with naturalist $(\beta 2.3(0.5-4.2$; $p=0.01)$ ). The rest of the associations were not significant. 
Table 3. Mixed-Effect Regression Analysis for Vitamin D Status and MI.

\begin{tabular}{|c|c|c|c|c|c|c|}
\hline \multirow{2}{*}{ Parameters } & \multicolumn{2}{|c|}{ All } & \multicolumn{2}{|c|}{ Boys } & \multicolumn{2}{|c|}{ Girls } \\
\hline & $\beta(95 \% \mathrm{CI})$ & $p$-Value & $\beta(95 \% \mathrm{CI})$ & $p$-Value & $\beta(95 \% \mathrm{CI})$ & $p$-Value \\
\hline Verbal & $\begin{array}{c}-2.20 \\
(-3.9--0.5)\end{array}$ & 0.01 & $1.58(-4.7-1.5)$ & 0.32 & $-1.03(-3.0-0.9)$ & 0.30 \\
\hline Logical & $1.77(0.2-3.3)$ & 0.03 & $2.27(-0.6-5.2)$ & 0.13 & $-0.07(-1.8-1.7)$ & 0.94 \\
\hline Visual & $0.72(-0.9-2.3)$ & 0.38 & $-2.51(-5.7-0.7)$ & 0.12 & $1.56(-0.2-3.3)$ & 0.08 \\
\hline Kinesthetic & $1.44(-0.1-3.0)$ & 0.07 & $5.64(2.8-8.5)$ & $<0.001$ & $0.48(-1.2-2.2)$ & 0.58 \\
\hline Musical & $\begin{array}{c}-1.33 \\
(-2.2--0.4)\end{array}$ & 0.004 & $0.99(-0.5-2.5)$ & 0.2 & $-1.19(-2.3-0.1)$ & 0.03 \\
\hline Intrapersonal & $1.05(-0.4-2.6)$ & 0.17 & $0.66(-2.2-3.5)$ & 0.65 & $0.92(-0.8-2.6)$ & 0.28 \\
\hline Interpersonal & $0.24(-1.3-1.8)$ & 0.77 & $-2.26(-5.0-0.5)$ & 0.11 & $-0.48(-2.3-1.3)$ & 0.60 \\
\hline Naturalist & $0.53(-1.1-2.2)$ & 0.52 & $-1.45(-4.3-1.4)$ & 0.32 & $2.31(0.5-4.2)$ & 0.01 \\
\hline $\begin{array}{l}\text { Existential } \\
\text { Emotional }\end{array}$ & $-1.48(-3.0-0.1)$ & 0.06 & $0.06(-2.6-2.8)$ & 0.96 & $-1.45(-3.2-0.3)$ & 0.10 \\
\hline
\end{tabular}

Note: Data presented as coefficient $\beta$ (95\% CI); $p$-values adjusted for age and BMI; significant at $<0.05$.

\section{Discussion}

The present study found that differences exist in MI of boys and girls, and that certain types of intelligence is associated with vitamin D status independent from age and BMI. Girls have higher levels of verbal, kinesthetic, musical, naturalist and existential intelligence than boys, who in turn, have higher logical intelligence. An extensive body of literature have documented sexual dimorphism in the estimation of MI, which the present study confirms [36-39]. However, other studies indicate no apparent sex-differences either on subscale level or total MI score. Our results are similar to a study done in Spain [40], in that Spanish boys had more logical-mathematical and interpersonal intelligence than girls, which was in contrast to a study done among Turkish children [41]. Whether the differences in MI of boys and girls have more to do with culture and education system variations across ethnic groups rather than biological needs further clarification.

The present study also showed that majority of students living in Riyadh are vitamin D deficient, with approximately $84.2 \%$ of the boys and $93.5 \%$ of the girls having $25(\mathrm{OH}) \mathrm{D}$ levels below $50 \mathrm{nmol} / \mathrm{L}$. This is consistent with recent local studies pointing to high prevalence of vitamin D deficiency among adolescents in Saudi Arabia was around 96\% [29,42]. Even among newborns, a study conducted in 2017 showed that $88 \%$ of newborns had levels of $25(\mathrm{OH}) \mathrm{D}<50 \mathrm{nmol} / \mathrm{L}$ [43]. Another study from our group in 331 Saudi children aged 6-17 years (153 boys and 178 girls) demonstrated that all subjects were vitamin $\mathrm{D}$ deficient (serum 25-(OH) vitamin $\mathrm{D}$ ) with the majority being moderately deficient $(71.6 \%)$ [44]. Increased prevalence among school aged children and adolescents has been reported, reflecting modern-day lifestyle changes, lack of knowledge about vitamin D sources (sun exposure and food) mostly among girls. The other explanation could be the fat distribution, with females having more fat percentage, decreasing vitamin D bioavailability [45].

Using mixed regression analysis, the present study showed a significant association between vitamin $D$ status and kinesthetic intelligence in boys and naturalist intelligence in girls. It is established that males are more physically active than females and this difference is more pronounced in adolescents [46], affecting kinesthetic intelligence. People with high kinesthetic intelligence more likely to perform sports activities which may require large spaces such as outdoor venues, thus acquiring vitamin D from its natural sources. The same concept may apply to girls, since the development of naturalist and visual intelligence require knowledge from different sceneries and natural environments, consequently influencing endogenous vitamin D levels from such outdoor exposures. It is most likely therefore that the significant associations to $25(\mathrm{OH}) \mathrm{D}$ elicited are an indirect consequence of enhancing these domains of intelligences and not vice versa. Potential mediators and predictors of these associations may include, but not limited to, physical activity, diet and socioeconomic status, all of which were not captured in the model. The last potential factor is particularly important as childhood socioeconomic status are associated with both vita- 
min D status and degree of psychometric intelligence [47,48]. Nevertheless, vitamin D is considered as an essential neuro-steroid with several brain actions [49]. Circulating vitamin $\mathrm{D}$ crosses brain barrier to be converted into active form of vitamin $\mathrm{D}(1,25(\mathrm{OH}) 2 \mathrm{D})$ [50]. One study observed the influence of vitamin $D$ on neurotransmitter changes and concluded that vitamin D deficiency alters brain changes [51]. In a review done by Freedman et al., there is a relation between micronutrient supplementation during pregnancy and childhood mental illness [52].

The results of the present study should be interpreted with caution taking into full consideration its limitations. First is the cross-sectional design which prevents causality among correlations elicited. Several factors affecting vitamin D status such as season, physical activity, socioeconomic status and dietary intake were also not included in the analysis and this can affect the strength of associations aside from the well-established covariates such as age and BMI. While some associations elicited between vitamin D status and MI were significant, the association itself is weak and as such the results are at most, suggestive. Lastly, the present results may only apply to adolescents, and associations of vitamin D status to MI maybe totally different in other populations in different life stages.

\section{Conclusions}

Among Arab adolescents, several types of MI are associated by vitamin D status in boys and girls, independent of age and BMI. Girls had higher levels of verbal, kinesthetic, musical, naturalist and existential intelligences than boys and boys have higher logical intelligence than girls. Vitamin D status is associated with kinesthetic intelligence in boys and naturalist intelligence in girls independent of age and BMI. These associations with $25(\mathrm{OH}) \mathrm{D}$ may be an indirect consequence of developing specific domains of intelligence that require outdoor environmental exposures. Prospective studies may determine whether vitamin D correction among adolescents may improve development of several types of MI.

Author Contributions: N.M.A.-D. contributed in the design, subject recruitments and data collection. A.S.M.M. carried out sample analysis, interpretation S.M.Y. wrote the manuscript. M.N.K.K. carried out statistical analysis. G.A. edited the final version of the manuscript. All authors have read and agreed to the published version of the manuscript.

Funding: This work was supported by the Researchers Supporting Project (RSP2021/21), King Saud University, Riyadh, Saudi Arabia.

Institutional Review Board Statement: The study was conducted according to the guidelines of the Declaration of Helsinki, and approved by the Ethics Committee of College of Science, King Saud University, Riyadh, Saudi Arabia (research project \# No. E-19-239 on 29 October 2019).

Informed Consent Statement: A written informed consent form was obtained from all subjects before their inclusion in this study.

Data Availability Statement: The data concerning this study is available from the corresponding author on reasonable request.

Conflicts of Interest: The authors declare no conflict of interest.

\section{References}

1. Ackerman, P.L.; Beier, M.E.; Boyle, M.O. Working memory and intelligence: The same or different constructs? Psychol. Bull. 2005, 131, 30-60. [CrossRef]

2. Dehn, N.; Schank, R. Handbook of Human Intelligence; Cambridge University Press: Cambridge, MA, USA, 1982.

3. Cattell, R.B.; Cattell, A.K.S. Measuring Intelligence with the Culture Fair Tests; Institute for Personality and Ability Testing: Champaign, IL, USA, 1960.

4. Sternberg, R.J. The Theory of Successful Intelligence. Gifted Educ. Int. 2000, 15, 4-21. [CrossRef]

5. Campione, J.C.; Brown, A.L. Toward a theory of intelligence: Contributions from research with retarded children. Intelligence 1978, 2, 279-304. [CrossRef]

6. Gardner, H. Development psychology after Piaget: An approach in terms of symbolization. Hum. Dev. 1979, 22, 73-88. [CrossRef]

7. Hatch, T.C.; Gardner, H. From testing intelligence to assessing competences: A pluralistic view of intellect. Roeper Rev. 1986, 8, 147-150. [CrossRef] 
8. Colom, R.; Karama, S.; Jung, R.E.; Haier, R.J. Human intelligence and brain networks. Dialogues Clin. Neurosci. $2010,12,489-501$.

9. Pellegrini, A.D. Psychological Bases for Early Education; John Wiley \& Sons: Hoboken, NJ, USA, 1988.

10. Howe, M.J. Encouraging the Development of Exceptional Skills and Talents; British Psychological Society: Leicester, UK, 1990.

11. Schutte, N.S.; Malouff, J.M.; Hall, L.E.; Haggerty, D.J.; Cooper, J.T.; Golden, C.J.; Dornheim, L. Development and validation of a measure of emotional intelligence. Personal. Individ. Differ. 1998, 25, 167-177. [CrossRef]

12. Hille, K.; Gust, K.; Bitz, U.; Kammer, T. Associations between music education, intelligence, and spelling ability in elementary school. Adv. Cogn. Psychol. 2011, 7, 1. [CrossRef]

13. Miendlarzewska, E.A.; Trost, W.J. How musical training affects cognitive development: Rhythm, reward and other modulating variables. Front. Neurosci. 2014, 7, 279. [CrossRef] [PubMed]

14. Nuallaong, W.; Nuallaong, T.; Preechadirek, N. Academic achievement from using the learning medium via a tablet device based on multiple intelligences in grade 1 elementary student. J. Med. Assoc. Thai 2015, 98, S24-S28.

15. Sheahan, L.; While, A.; Bloomfield, J. An exploratory trial exploring the use of a multiple intelligences teaching approach (MITA) for teaching clinical skills to first year undergraduate nursing students. Nurse Educ. Today 2015, 35, 1148-1154. [CrossRef] [PubMed]

16. Hearne, D.; Stone, S. Multiple intelligences and underachievement: Lessons from individuals with learning disabilities. J. Learn. Disabil. 1995, 28, 439-448. [CrossRef] [PubMed]

17. Al-Musharaf, S.; Fouda, M.A.; Turkestani, I.Z.; Al-Ajlan, A.; Sabico, S.; Alnaami, A.M.; Wani, K.; Hussain, S.D.; Alraqebah, B.; Al-Serehi, A.; et al. Vitamin D Deficiency Prevalence and Predictors in Early Pregnancy among Arab Women. Nutrients 2018, 10, 489. [CrossRef] [PubMed]

18. Al-Daghri, N.M.; Al-Saleh, Y.; Aljohani, N.; Alokail, M.; Al-Attas, O.; Alnaami, A.M.; Sabico, S.; Alsulaimani, M.; Al-Harbi, M.; Alfawaz, H.; et al. Vitamin D Deficiency and Cardiometabolic Risks: A Juxtaposition of Arab Adolescents and Adults. PLoS ONE 2015, 10, e0131315. [CrossRef] [PubMed]

19. Al-Daghri, N.M.; Torretta, E.; Capitanio, D.; Fania, C.; Guerini, F.R.; Sabico, S.B.; Clerici, M.; Gelfi, C. Intermediate and low abundant protein analysis of vitamin D deficient obese and non-obese subjects by MALDI-profiling. Sci. Rep. 2017, 7, 12633. [CrossRef] [PubMed]

20. Al Saleh, Y.; Beshyah, S.A.; Hussein, W.; Almadani, A.; Hassoun, A.; Al Mamari, A.; Ba-Essa, E.; Al-Dhafiri, E.; Hassanein, M.; Fouda, M.A.; et al. Diagnosis and management of vitamin D deficiency in the Gulf Cooperative Council (GCC) countries: An expert consensus summary statement from the GCC vitamin D advisory board. Arch. Osteoporos. 2020, 15, 35. [CrossRef]

21. Alguwaihes, A.M.; Al-Sofiani, M.E.; Megdad, M.; Albader, S.S.; Alsari, M.H.; Alelayan, A.; Alzahrani, S.H.; Sabico, S.; Al-Daghri, N.M.; Jammah, A.A. Diabetes and Covid-19 among hospitalized patients in Saudi Arabia: A single-centre retrospective study. Cardiovasc. Diabetol. 2020, 19, 205. [CrossRef] [PubMed]

22. Alguwaihes, A.M.; Sabico, S.; Hasanato, R.; Al-Sofiani, M.E.; Megdad, M.; Albader, S.S.; Alsari, M.H.; Alelayan, A.; Alyusuf, E.Y.; Alzahrani, S.H.; et al. Severe vitamin D deficiency is not related to SARS-CoV-2 infection but may increase mortality risk in hospitalized adults: A retrospective case-control study in an Arab Gulf country. Aging Clin. Exp. Res. 2021, 33, 1415-1422. [CrossRef] [PubMed]

23. Sabico, S.; Enani, M.A.; Sheshah, E.; Aljohani, N.J.; Aldisi, D.A.; Alotaibi, N.H.; Alshingetti, N.; Alomar, S.Y.; Alnaami, A.M.; Amer, O.E.; et al. Effects of a 2-Week 5000 IU versus 1000 IU Vitamin D3 Supplementation on Recovery of Symptoms in Patients with Mild to Moderate Covid-19: A Randomized Clinical Trial. Nutrients 2021, 13, 2170. [CrossRef]

24. Ibi, M.; Sawada, H.; Nakanishi, M.; Kume, T.; Katsuki, H.; Kaneko, S.; Shimohama, S.; Akaike, A. Protective effects of 1 alpha,25$(\mathrm{OH})(2) \mathrm{D}(3)$ against the neurotoxicity of glutamate and reactive oxygen species in mesencephalic culture. Neuropharmacology 2001, 40, 761-771. [CrossRef]

25. Etgen, T.; Sander, D.; Bickel, H.; Sander, K.; Forstl, H. Vitamin D deficiency, cognitive impairment and dementia: A systematic review and meta-analysis. Dement. Geriatr. Cogn. Disord. 2012, 33, 297-305. [CrossRef]

26. Mayne, P.E.; Burne, T.H.J. Vitamin D in Synaptic Plasticity, Cognitive Function, and Neuropsychiatric Illness. Trends Neurosci. 2019, 42, 293-306. [CrossRef]

27. Holick, M.F. Sunlight and vitamin D for bone health and prevention of autoimmune diseases, cancers, and cardiovascular disease. Am. J. Clin. Nutr. 2004, 80, 1678S-1688S. [CrossRef]

28. Holick, M.F. Vitamin D deficiency. N. Engl. J. Med. 2007, 357, 266-281. [CrossRef]

29. Al-Daghri, N.M.; Hussain, S.D.; Ansari, M.G.A.; Khattak, M.N.K.; Aljohani, N.; Al-Saleh, Y.; Al-Harbi, M.Y.; Sabico, S.; Alokail, M.S. Decreasing prevalence of vitamin D deficiency in the central region of Saudi Arabia (2008-2017). J. Steroid Biochem. Mol. Biol. 2021, 212, 105920. [CrossRef]

30. Chakhtoura, M.; Rahme, M.; Chamoun, N.; Fuleihan, G.E.H. Vitamin D in the Middle East and North Africa. Bone Rep. 2018, 8, 135-146. [CrossRef] [PubMed]

31. Gáll, Z.; Székely, O. Role of Vitamin D in Cognitive Dysfunction: New Molecular Concepts and Discrepancies between Animal and Human Findings. Nutrients 2021, 13, 3672. [CrossRef] [PubMed]

32. Melough, M.M.; Murphy, L.E.; Graff, J.C.; Derefinko, K.J.; LeWinn, K.Z.; Bush, N.R.; Enquobahrie, D.A.; Loftus, C.T.; Kocak, M.; Sathyanarayana, S.; et al. Maternal Plasma 25-Hydroxyvitamin D during Gestation Is Positively Associated with Neurocognitive Development in Offspring at Age 4-6 Years. J. Nutr. 2021, 151, 132-139. [CrossRef] 
33. Walton, C.; Isaac, A.; Kerr, M. Prevalence of vitamin D deficiency in people with learning disability: A systematic review. Br. J. Learn. Disabil. 2019, 47, 279-288. [CrossRef]

34. McKenzie, W. Multiple Intelligences Survey. Available online: http://surfaquarium.com/MI/MIinvent.htm (accessed on 8 December 2021).

35. Hajhashemi, K.; Wong, B.E. A Validation Study of the Persian Version of Mckenzie's (1999) Multiple Intelligences Inventory to Measure MI Profiles of Pre-University Students. Pertanika J. Soc. Sci. Humanit. 2010, 18, 343-355.

36. Furnham, A.; Akande, A. African parents' estimates of their own and their children's multiple intelligences. Curr. Psychol. 2004, 22, 281-294. [CrossRef]

37. Furnham, A.; Chamorro-Premuzic, T. Estimating one's own and one's relatives' multiple intelligence: A study from Argentina. Span J. Psychol. 2005, 8, 12-20. [CrossRef]

38. Furnham, A.; Hosoe, T.; Tang, T.L.-P. Male hubris and female humility? A cross-cultural study of ratings of self, parental, and sibling multiple intelligence in America, Britain, and Japan. Intelligence 2002, 30, 101-115. [CrossRef]

39. Barnard, L.; Olivarez, A. Self-estimates of multiple, g factor, and school-valued intelligences. N. Am. J. Psychol. 2007, 9, 501-510.

40. Llor, L.; Fernando, M.; Ferrandiz, C.; Hernandez, D.; Sainz, M.; Prietro, M.D.; Fernandez, M.C. Inteligencias múltiples y alta habilidad [Multiple intelligences and high skills]. Aula Abierta 2012, 40, 27-38.

41. Beceren, B.Ö. Determining multiple intelligences pre-school children (4-6 age) in learning process. Procedia Soc. Behav. Sci. 2010, 2, 2473-2480. [CrossRef]

42. AlBuhairan, F.S.; Tamim, H.; Al Dubayee, M.; AlDhukair, S.; Al Shehri, S.; Tamimi, W.; El Bcheraoui, C.; Magzoub, M.E.; de Vries, N.; Al Alwan, I. Time for an Adolescent Health Surveillance System in Saudi Arabia: Findings From "Jeeluna". J. Adolesc. Health 2015, 57, 263-269. [CrossRef] [PubMed]

43. Fouda, M.A.; Turkestani, I.Z.; Almusharraf, S.; Al-Ajlan, A.; Angkaya-Bagayawa, F.F.; Sabico, S.; Mohammed, A.G.; Hassanato, R.; Al-Serehi, A.; Alshingetti, N.M.; et al. Extremely High Prevalence of Maternal and Neonatal Vitamin D Deficiency in the Arab Population. Neonatology 2017, 112, 225-230. [CrossRef] [PubMed]

44. Al-Othman, A.; Al-Musharaf, S.; Al-Daghri, N.M.; Krishnaswamy, S.; Yusuf, D.S.; Alkharfy, K.M.; Al-Saleh, Y.; Al-Attas, O.S.; Alokail, M.S.; Moharram, O.; et al. Effect of physical activity and sun exposure on vitamin D status of Saudi children and adolescents. BMC Pediatrics 2012, 12, 92. [CrossRef]

45. Wortsman, J.; Matsuoka, L.Y.; Chen, T.C.; Lu, Z.; Holick, M.F. Decreased bioavailability of vitamin D in obesity. Am. J. Clin. Nutr. 2000, 72, 690-693. [CrossRef] [PubMed]

46. Cui, X.; Gooch, H.; Groves, N.J.; Sah, P.; Burne, T.H.; Eyles, D.W.; McGrath, J.J. Vitamin D and the brain: Key questions for future research. J. Steroid Biochem. Mol. Biol. 2015, 148, 305-309. [CrossRef]

47. Al-Agha, A.E.; Alsharief, A.A.; Ahmed, M.S.; Nassir, A.Y. The Effect of Socioeconomic Status on Vitamin D Level in Children's and Adolescents Living at Jeddah, Saudi Arabia. Evid. Based Med. Pract. 2016, 2, 109. [CrossRef]

48. Takeuchi, H.; Taki, Y.; Asano, K.; Asano, M.; Sassa, Y.; Yokota, S.; Kotozaki, Y.; Nouchi, R.; Kawashima, R. Childhood socioeconomic status is associated with psychometric intelligence and microstructural brain development. Commun. Biol. 2021, 4, 470. [CrossRef] [PubMed]

49. Lenhart, C.M.; Hanlon, A.; Kang, Y.; Daly, B.P.; Brown, M.D.; Patterson, P. Gender Disparity in Structured Physical Activity and Overall Activity Level in Adolescence: Evaluation of Youth Risk Behavior Surveillance Data. Int. Sch. Res. Not. 2012, $2012,674936$. [CrossRef]

50. Holick, M.F. Vitamin D and brain health: The need for vitamin D supplementation and sensible sun exposure. J. Intern. Med. 2015, 277, 90-93. [CrossRef] [PubMed]

51. Yates, N.J.; Tesic, D.; Feindel, K.W.; Smith, J.T.; Clarke, M.W.; Wale, C.; Crew, R.C.; Wharfe, M.D.; Whitehouse, A.J.O.; Wyrwoll, C.S. Vitamin D is crucial for maternal care and offspring social behaviour in rats. J. Endocrinol. 2018, 237, 73-85. [CrossRef]

52. Freedman, R.; Hunter, S.K.; Hoffman, M.C. Prenatal Primary Prevention of Mental Illness by Micronutrient Supplements in Pregnancy. Am. J. Psychiatry 2018, 175, 607-619. [CrossRef] 